\title{
Temporal Change of Drainage Structures in Forest Roads (Study of Bentler Forest Enterprise 2009-2019)
}

\author{
Tolga Ozturk \\ Istanbul University-Cerrahpasa, Faculty of Forestry, 34473, Bahcekoy/Istanbul, Turkey
}

\begin{abstract}
The forest roads provide access to forest resources in carrying out main forestry activities such as protection, afforestation, management, recreation and firefighting. Long-term, trouble-free and safe use of forest roads is possible through the construction of the drainage structures and walls along the road alignment. The drainage structures and protective structures used in forest roads are various types. These are dip drains, pipes, culverts, bridges, water-bars and walls. The main task of all drainage structures and walls is protecting the forest roads against external aggressors. In this study, drainage structures on a sample road were investigated. Along the forest road alignment, changes of drainage structures over 10 years were observed. As a result of the study, current conditions of drainage structures were revealed and various suggestions were presented.
\end{abstract}

Keywords: Drainage structures, Culvert, Forest road, Positioning, Sizing

\section{Introduction}

Forests should be constructed according to technical standards and particular attention needs to be paid to forest roads in planning and management stages to developed sustainable forest infrastructure (Eskandri and Hosseini, 2013). The forest roads provide access to different zones of forest area for important activities such as harvesting, plantation, protection against fire and insects, social activities, etc. Roads are constructed to serve for a long time. However, even a single closed road has an impact on the transport system and can also affect other social activities (Kalantari and Folkeson, 2013). Forest roads are affected by the water coming to its surface and waters coming from the basin crossed by streams (Bayoğlu and Hasdemir, 1991). In case the road surface is constantly wet due to the precipitation water, especially after the harvesting activities, large deformations occur on the road surface by the passage of heavy trucks. Besides, the waters coming from the cut slope and flowing down the road surface and continue to flow down the embankment slope also cause great damage to the road and the embankment slope can be damaged by erosion over time. Drainage facilities undertake to protect forest roads against all these negative effects of rainfall waters.

The drainage system is one of the most important technical structures in the forest road construction (Rezvani, 2012). Road location and drainage of forest roads, construction areas, and other areas of forestry activities are the critical factors that can affect water quality, erosion and road costs. Drainage includes controlling surface and subsurface water for forest roads and its neighborhood areas. Planning stages of drainage structures or protective structures are very important. If drainage structures are not planned, sized and positioned correctly, they can be easily clogged with sediment or wood materials. The determination of the types and dimensions of the pipes, culverts, and bridges to be constructed in the places where the road routes cut the river beds are of great importance in terms of the safety and economy of these facilities and consequently the roads (Çalışkan et al., 2006). The determination of the type and size of hydraulic engineering structures, as well as the construction of these structures in suitable places according to the terrain and road conditions, are of great importance in the success of the road's drainage (Schwab, 1994). A cost estimate to build a forest road must include not only the initial construction cost but also future maintenance costs (Anonymous, 2019).

For forest roads use different drainage structures such as pipe, culvert, ditch, bridge and dip-drain (Öztürk, 2010). The most common form of drainage structure on forest roads are culverts (Anonymous, 2010). A good culvert stream-crossing or cross-drain depends on sound installation procedures, as well as proper culvert type, length, size and location. Poor choices in these factors often cause culvert failure, resulting in an unusable road, costly replacement, soil loss and damage to water quality (Anonymous, 2009). Water is one of the major causes of 
the damage to roads (Kalantari and Folkeson, 2013). Moving water, such as water running downhill on a forest road surface, can be thought of as a source of kinetic energy. This energy is one of the primary physical causes of erosion often seen on forest roads (Anonymous, 2019). The important situation for road engineering, drainage structures should be used on long-term future on forest roads. In Turkey, for drainage structures, the prescribed lifetime is between 30 and 40 years. But, these structures should be very good stages such as planning, sizing, positioning, construction and maintenance.

In this study, the current status of 7 culverts built-in 2008 on the selected forest road was examined regularly every year and the changes in the culverts during the past 10 years were revealed. As a result of these changes, positive and negative situations in planning, sizing, positioning, material selection and construction of these drainage structures were presented. In the light of these opinions, various suggestions were made in terms of planning, sizing, positioning and construction of drainage structures.

\section{Material and Methods}

\subsection{Research Area}

In this study, a forest road within the Bentler Forest Enterprises affiliated to Istanbul Bahçeköy Forestry Operation Directorate was chosen as the research area. The starting point of the road route is $90 \mathrm{~m}$ high from the sea, and the road ended at a height of $170 \mathrm{~m}$. The total length of the road is $2500 \mathrm{~m}$ and at the same time, the longitudinal slope of the road route varies between 2-8\%. Commercial tree species in the area are Maritime pine (Pinus pinaster Aiton.) and Oak (Quercus sp.).

The soil type of the area along the road route is claysandy soil (Anonymous, 2010). The clay type of soil increases the surface flow on and around the road. The annual average amount of precipitation in the region is $1093.3 \mathrm{~mm}$. Seven culverts were built on this road route in 2008. The six of these culverts are decked culverts and one of them is box culvert. Meteorological data of the Istanbul region in which the study area is located is shown in Table 1.

Table 1. Meteorological data of research area (1929-2018) (Akgul et.al., 2019)

\begin{tabular}{ccccccc}
\hline Months & $\begin{array}{c}\text { Average } \\
\text { Temperature } \\
\left({ }^{\circ} \mathrm{C}\right)\end{array}$ & $\begin{array}{c}\text { Ave. Max. } \\
\text { Temperature } \\
\left({ }^{\circ} \mathrm{C}\right)\end{array}$ & $\begin{array}{c}\text { Ave. Min. } \\
\text { Temperature } \\
\left({ }^{\circ} \mathrm{C}\right)\end{array}$ & $\begin{array}{c}\text { Average } \\
\text { sunshine } \\
\text { duration } \\
(\text { Hour })\end{array}$ & $\begin{array}{c}\text { Ave. } \\
\text { number of } \\
\text { rainy days } \\
(\text { number })\end{array}$ & $\begin{array}{c}\text { Ave. of total } \\
\text { monthly } \\
\text { precipitation } \\
(\mathrm{mm})\end{array}$ \\
\hline January & 6.0 & 8.5 & 3.2 & 2.9 & 17.3 & 105.5 \\
\hline February & 6.1 & 9.0 & 3.1 & 3.6 & 15.0 & 77.8 \\
\hline March & 7.7 & 11.0 & 4.3 & 4.6 & 13.7 & 71.9 \\
\hline April & 12.0 & 15.5 & 7.7 & 6.4 & 10.2 & 45.6 \\
\hline May & 16.7 & 20.1 & 12.2 & 8.7 & 8.0 & 34.4 \\
\hline June & 21.4 & 24.7 & 16.6 & 10.5 & 6.2 & 36.3 \\
\hline July & 23.8 & 26.7 & 19.5 & 11.4 & 4.3 & 34.1 \\
\hline August & 23.8 & 26.9 & 20.2 & 10.5 & 5.0 & 39.6 \\
\hline September & 20.1 & 23.8 & 16.9 & 8.2 & 7.7 & 64.6 \\
\hline October & 15.7 & 19.2 & 13.0 & 5.6 & 11.2 & 87.1 \\
\hline November & 11.7 & 14.9 & 9.0 & 4.0 & 12.9 & 102.2 \\
\hline December & 8.2 & 10.9 & 5.5 & 2.7 & 16.9 & 123.9 \\
\hline Yearly & 14.4 & 17.6 & 10.9 & 6.6 & 10.7 & 68.6 \\
\hline
\end{tabular}

\subsection{Method}

After the culvert constructions were completely completed, all information such as the dimensions of the culverts, their length, bridge thickness, the wall dimensions at the entrance and exit, and the location of the culvert on the road route were collected during the first fieldwork conducted in September 2008. The geographical coordinates of the points where the culverts were built were localized by Garmin Etrex brand handheld GPS. The forest road in the research area is a type $B$ forest road with a width of $4 \mathrm{~m}$ and a ditch width of $1 \mathrm{~m}$. After the construction of the culverts, the current conditions of the culverts were monitored frequently in the summer months every year after the winter season ended.

Once the field studies were completed, 1/25000 scale maps of the study area were digitized via ArcGIS 9.3 computer program in the office. GPS data collected during field studies were again transferred to ArcGIS and the locations of the culverts were marked on the road route where the study was conducted. After these studies, sub-basins of the study field and culverts at the intersections of these basins with the forest road were determined. 


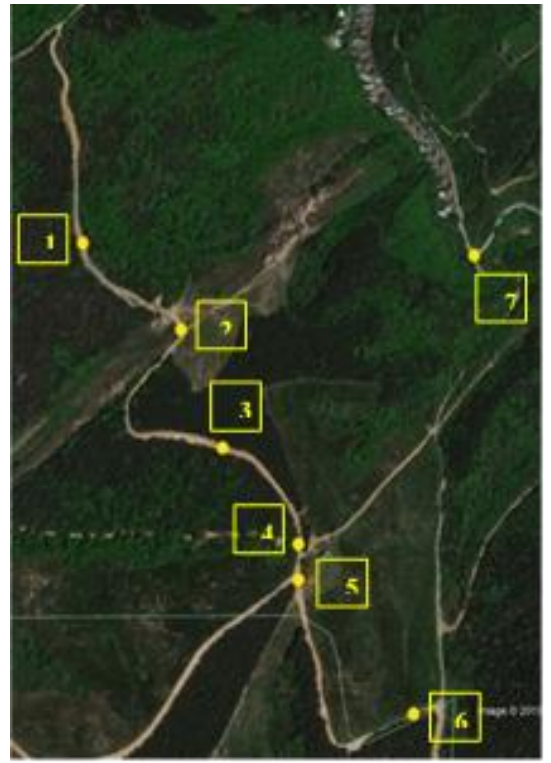

Figure 1. Forest road alignment and culvert points (URL1)

In the field studies, it was first examined whether the culverts were located at the basin exit points and suitable places and whether the types and dimensions of the constructed culverts were suitable for the area. During this examination, the cross-sectional area of the water that could come out of the basin was determined by the Talbot formula, and then the constructed culvert size and the correct culvert size were compared.

\subsection{Sizing of Drainage Structures}

When a stream crosses the road or when the water coming to the dip drains due to surface drainage must be passed under the road to the opposite side, it is necessary to choose and determine the sizes of a hydraulic structure which may cross the water that the stream can bring during the greatest flood in a certain period (usually 50 years) under the road in a way of not damaging the road to be built. When sizing the bridge and culverts, in addition to the highest level of stream in that calculated period, the margin of safety between the lowest part of the superstructure and the highest water level should not be less than $1.5 \mathrm{~m}$ in bridges and culverts where streams that bring trees and large logs, $1 \mathrm{~m}$ where streams do not bring trees and logs, and $0.5 \mathrm{~m}$ in the other culverts (Ozturk and Inan, 2010).

The first method used in the sizing of drainage facilities was made according to the "Talbot Formula" metric dimensions. Talbot formula;

$$
\begin{aligned}
& \mathrm{S}=5,791 \cdot \mathrm{C} \cdot \sqrt[4]{A^{3}} \\
& \mathrm{~S}=\text { Cross-section of the drainage structure }\left(\mathrm{m}^{2}\right) \\
& \mathrm{A}=\text { Area of the catchment basin }\left(\mathrm{km}^{2}\right) \\
& \mathrm{C}=\text { A coefficient based on topography of the water basin }
\end{aligned}
$$

Since the C coefficient directly affects the result in the calculations, it must be determined precisely. After determining the cross-sectional area of the drainage structure with these formulas and calculations, the type of drainage facility should be selected with the flow calculations. In the use of this table, various factors such as the topographic condition of the precipitation basin, the soil structure of the field and vegetation cover should be taken into account. Table 1 was used to determine the $\mathrm{C}$ coefficient (Bayoğlu, 1997).

Table 2. Determination of Talbot coefficient according to land types (OGM 2008)

\begin{tabular}{lcc}
\hline Area Types & $\begin{array}{c}\text { Slope } \\
\text { Classification }\end{array}$ & $\begin{array}{c}\text { C Talbot } \\
\text { Coefficient }\end{array}$ \\
\hline Flat, permeable, all covered with vegetation & $\% 10-20$ & 0,2 \\
Flat, permeable, leafy forest-covered land & $\% 10-30$ & 0,3 \\
Flat, permeable, coniferous forest-covered land & $\% 10-30$ & 0,4 \\
Rough, medium permeable, vegetative (leafy and coniferous) layers 3 lands & $\% 30-50$ & 0,5 \\
Rough, medium permeable, vegetative (leafy and coniferous) layers 0-2 & $\% 30-50$ & 0,6 \\
covered area & $\% 40-60$ & 0,7 \\
Rugged, impermeable land, vegetation 0-1 covered land & $\% 60 \leq$ & 0,8 \\
Steep, forest-covered, permeable land & $\% 60 \leq$ & 0,9 \\
Very steep, bare, impermeable & & \\
\hline
\end{tabular}




\section{Results}

One of the total 7 culverts which were in the study field was in the location of Derekayalar-Taşocağ 1 along the road with code number 25 and was a bridge culvert with dimensions of $0.80 \mathrm{x} 0.80 \mathrm{~m}$; as for that the other one was a box culvert at bigger dimensions and constructed over a continuously flowing stream. All culverts which were constructed in the location of Alaypınar- Ayazağa along the road with code number 26 were bridge culverts with dimensions of $0.80 \times 0.80 \mathrm{~m}$. There were headwalls at the entrance and exit sections of all culverts.

These headwalls protected the culvert and the road against the destructive effect of water at the entrance. The width of the headwalls varied between 1-1.5 m and the height of them varied between 0.8-2.0 m. Also, the headwalls at the exit point of the culvert prevented the culvert from any damage by any land flow in the embankment part of the road and made the road more stable. The general and technical information collected about the culverts as a result of the fieldwork in August 2008 is shown in Table 3.

Using the Talbot formula according to the sub-basins determined via the ArcGIS 9.3 computer program and their fields, the minimum cross-sectional areas were calculated according to the size of the basins. Table 4 shows whether the culverts were suitable for their locations as considering their calculated cross-sectional areas or not. It is very important to know the precipitation amount of the area to determine the sizes and types of drainage structures.

Table 3. The general condition of drainage structures in the research area

\begin{tabular}{ccccccccc}
\hline & \multicolumn{2}{c}{ Coordinates } & Drainage & \begin{tabular}{c} 
Internal \\
Nidth \\
\cline { 2 - 6 }$(\mathrm{cm})$
\end{tabular} & $\begin{array}{c}\text { Internal } \\
\text { height } \\
(\mathrm{cm})\end{array}$ & $\begin{array}{c}\text { Deck } \\
\text { thickness } \\
(\mathrm{cm})\end{array}$ & $\begin{array}{c}\text { Length } \\
(\mathrm{m})\end{array}$ & Headwall \\
\hline 1 & 666763 & 4558056 & D.Culvert & 80 & 80 & 20 & 5 & Existing \\
2 & 666918 & 4557015 & D.Culvert & 80 & 80 & 20 & 8 & Existing \\
3 & 667213 & 4557534 & D.Culvert & 80 & 80 & 20 & 5 & Existing \\
4 & 667219 & 4557534 & D.Culvert & 80 & 80 & 20 & 5 & Existing \\
5 & 667443 & 4557465 & D.Culvert & 80 & 80 & 20 & 5 & Existing \\
6 & 667483 & 4557248 & D.Culvert & 80 & 80 & 20 & 5 & Existing \\
7 & 667510 & 4557434 & B.Culvert & 300 & 150 & 30 & 6 & Existing \\
\hline
\end{tabular}

Table 4. Calculation of culvert cross-sections according to Talbot formula

\begin{tabular}{|c|c|c|c|c|c|c|c|}
\hline No & $\begin{array}{c}\text { Basin } \\
\text { area } \\
\left(\mathrm{km}^{2}\right)\end{array}$ & $\begin{array}{c}\text { Talbot } \\
\text { Coefficient }\end{array}$ & $\begin{array}{l}\text { Cross- } \\
\text { section } \\
\left(\mathrm{m}^{2}\right)\end{array}$ & $\begin{array}{l}\text { Required } \\
\text { cross- } \\
\text { section } \\
\left(\mathrm{m}^{2}\right) \\
\end{array}$ & $\begin{array}{l}\text { Existing } \\
\text { cross- } \\
\text { section } \\
\left(\mathrm{m}^{2}\right) \\
\end{array}$ & Relevance & Explanation \\
\hline 1 & 0.19 & 0.6 & 1.00 & 1.21 & 0.64 & Not relevance & Larger size* \\
\hline 2 & 0.11 & 0.6 & 0.66 & 0.81 & 0.64 & Not relevance & Larger size \\
\hline 3 & 0.17 & 0.6 & 0.92 & 1.00 & 0.64 & Not relevance & Larger size \\
\hline 4 & 0.35 & 0.6 & 1.58 & 1.69 & 0.64 & Not relevance & Box culvert** \\
\hline 5 & 0.19 & 0.6 & 1.00 & 1.21 & 0.64 & Not relevance & Larger size \\
\hline 6 & - & 0.6 & - & - & 0.64 & Relevance & Ditch \\
\hline 7 & 0.40 & 0.6 & 1.74 & 1.74 & 4.50 & Relevance & Using \\
\hline
\end{tabular}

*Larger size: The large size culvert should be used in this point.

***Box culvert: Box culvert should be used at this point.

As a result of the studies carried out in the field, it was found that the cross-section areas of the culverts with the number of 1,2, 3, 4 and 5 were not suitable as a result of the calculations made in the drainage structures and the cross-section areas. Besides, the cross-section areas were found to be small for these five culverts.

On the other hand, the calculation could not be made for culvert number six which was constructed to transfer the water coming from the dip drains to the opposite side of the road since there was no basin area in the field of this culvert. It was determined that the box culvert was made larger than normal, but it will be suitable in terms of 100 years of precipitation and pass materials such as trees and branches that could come from the stream. Besides, culverts with number $2,3,4,5$ and 6 were constructed perpendicular to the axis of the road. Therefore, it was observed that there was a large sediment accumulation at the entrance and exit points of these culverts.

The forest road, which is located in the Bentler Forest Management Directorate, regularly visited between May and June every year from May 2009 until 2019, and the final states of the engineering structures after the winter season were examined. As a result of this examination; there were observed no breakage, deterioration, cracking or rupture in the headwalls of all culverts along the roads. Maintenance work was carried out on these roads by a grader in April 2009. The ditches and platform of the road were cleaned. As a result of all field works between 2009 and 2019, the operating status of 7 culverts along the road route and their status by years are given in Table 5 . 
Table 5. Status of inlets and exits of culverts by years

\begin{tabular}{cccccccccl}
\hline & \multicolumn{3}{c}{ Culvert entrance } & \multicolumn{4}{c}{$\begin{array}{c}\text { Culvert outlet } \\
\text { closure rate }(\%)\end{array}$} & \multirow{2}{*}{ Explanation } \\
\cline { 2 - 8 } & 2009 & 2012 & 2016 & 2019 & 2009 & 2012 & 2016 & 2019 & \\
\hline 1 & 20 & 45 & 75 & 90 & 15 & 40 & 60 & 85 & Not functioning \\
2 & 30 & 60 & 100 & 100 & 25 & 65 & 100 & 100 & Not functioning \\
3 & 20 & 60 & 90 & 100 & 20 & 50 & 90 & 100 & Closed \\
4 & 0 & 20 & 45 & 65 & 0 & 10 & 40 & 60 & Functioning \\
5 & 10 & 30 & 75 & 90 & 10 & 30 & 65 & 85 & Not functioning \\
6 & 25 & 75 & 100 & 100 & 20 & 60 & 90 & 100 & Closed \\
7 & 0 & 0 & 0 & 0 & 0 & 0 & 0 & 0 & Functioning \\
\hline
\end{tabular}

The exit and entrance grades of the culvert number 5 were below the road grade and were very close to each other. In addition, the exit point of the culvert was the endpoint of a fire road, and all sediment and rainfall waters coming from the slope of the fire road were filled to the part of the culvert where the exit was constructed. Since the entrance section of this culvert was filled with water from road dip drains, it could not be even named for entrance or exit. At both points, even at the end of the first year after the construction date, sediment accumulation started and at the end of the tenth year, the culvert was filled with $90 \%$ sediment and lost its function (Figure 2). The culvert number 6 was constructed perpendicularly to the road so that the flow could not be provided easily. Therefore, it was observed that all sediment and precipitation waters coming from the dip drain accumulate at the entrance and exit of the culverts and fill the culverts. If these culverts were constructed at $30^{\circ}-45^{\circ}$ angle by road, sediment flow would occur through the culverts and thus the culvert entrance would not be filled with sediment (Figure 3).

Since the culvert number 2 was completely trapped under sediment, both sides of the culvert were closed and could not be functional (Figure 4). However, the culvert number 7 fulfils its function without any problems since it was in front of a stream that constantly carried water and was constructed in necessary sizes (Figure 5).
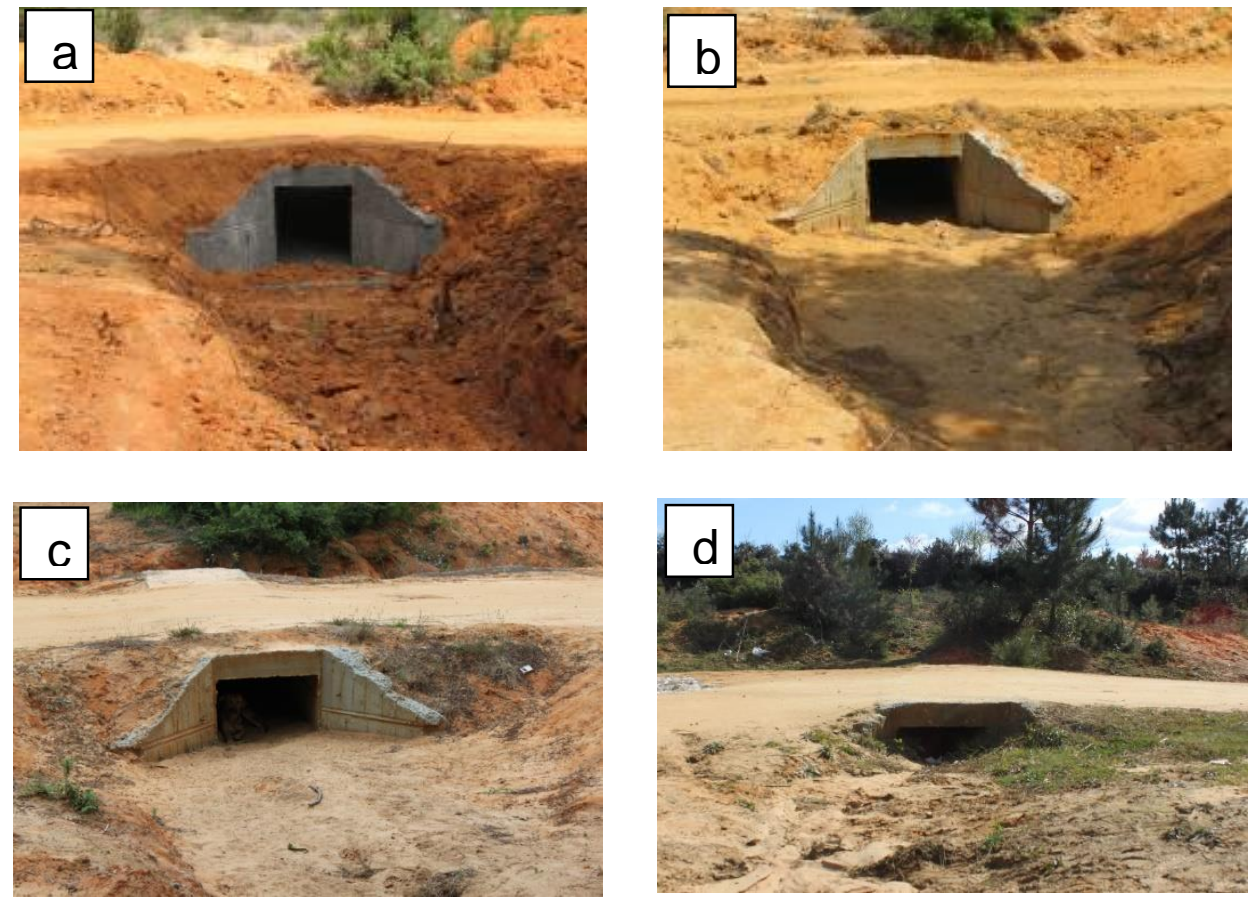

Figure 2. Fifth culvert photos 2009 (a), 2012 (b), 2016 (c) and 2019 (d) 

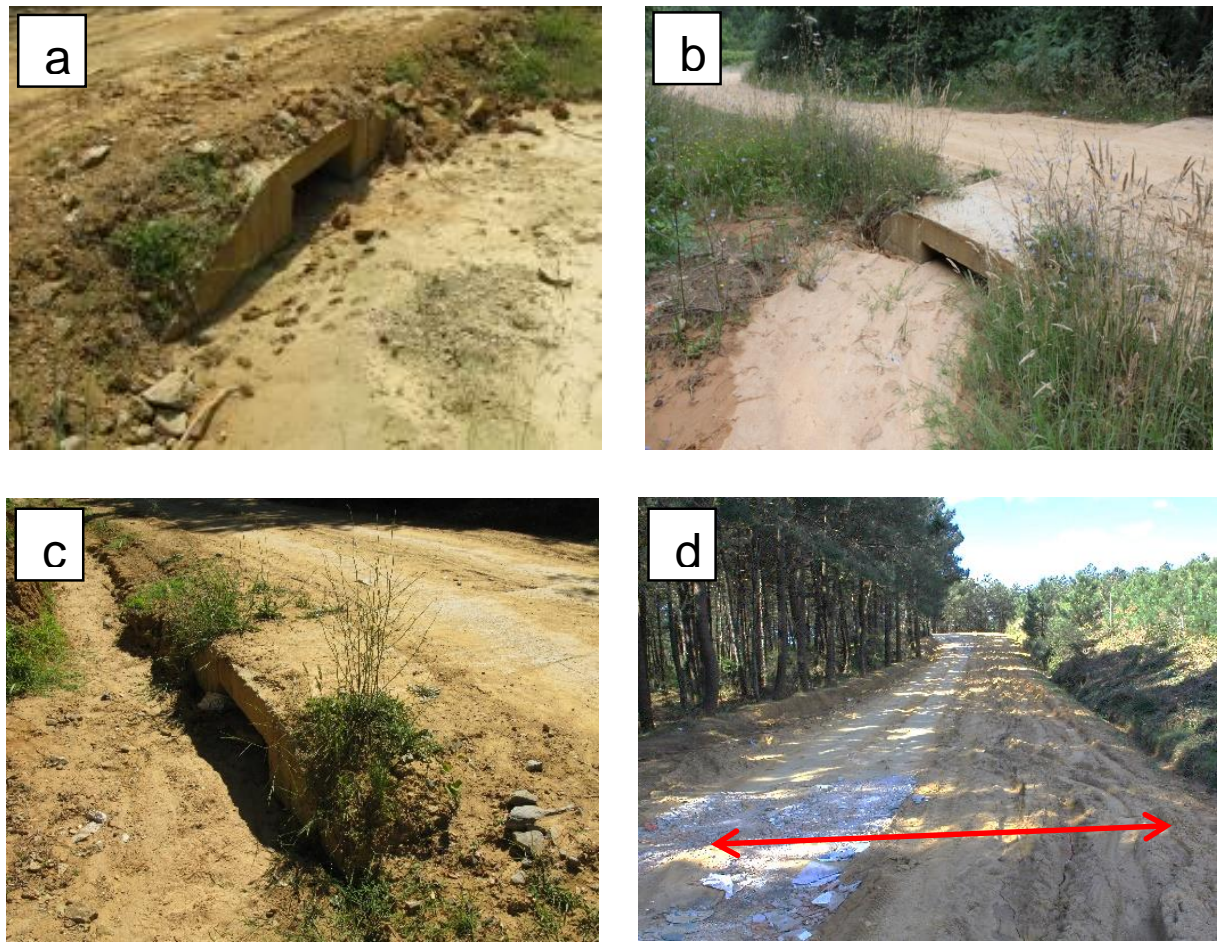

Figure 3. Sixth culvert photos 2009 (a), 2012 (b), 2016 (c) and 2019 (d)

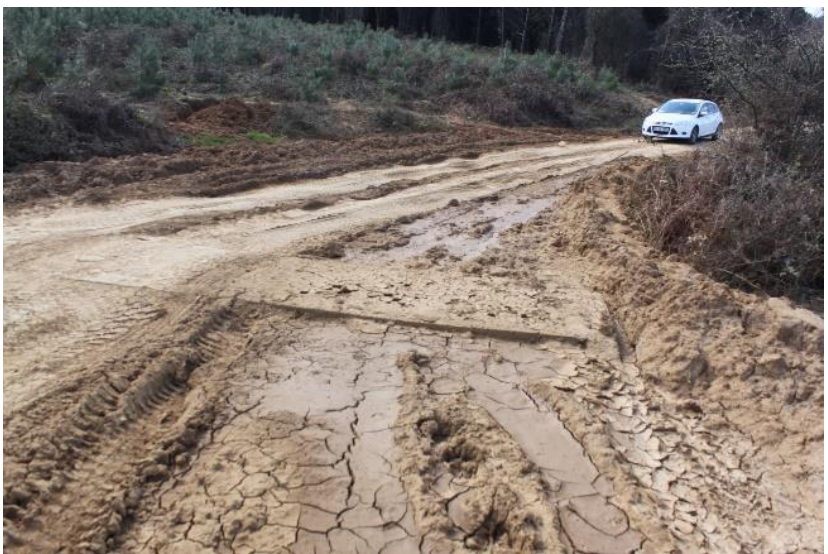

Figure 4. Culvert completely covered with sediment

\section{Discussion}

As a result, only one of the 7 culverts constructed within the area was able to fully function within the 10 years since 2008, the year of construction of the culverts. This culvert was the largest in the area and was a bow culvert constructed on the stream bed. Culverts 3 and 6 along the road route were completely closed. Since the entrance and exit parts of these culverts were completely filled with sediment, even the locations of the culverts were not seen. Since the culverts 1, 2 and 5 were considerably filled with sediment, they could not perform their functions. At the same time, these culverts were to be completely closed at the end of one winter season. As considering another culvert, culvert number 4 could operate at its $40 \%$ efficiency. If any maintenance in this culvert is not carried out, it will lose its function as soon as possible. When these culverts along the road route are evaluated; first, it was understood that only two of these 7 culverts (number 6 and 7) were correctly sized according to their location. However, positioning of some culverts along the road

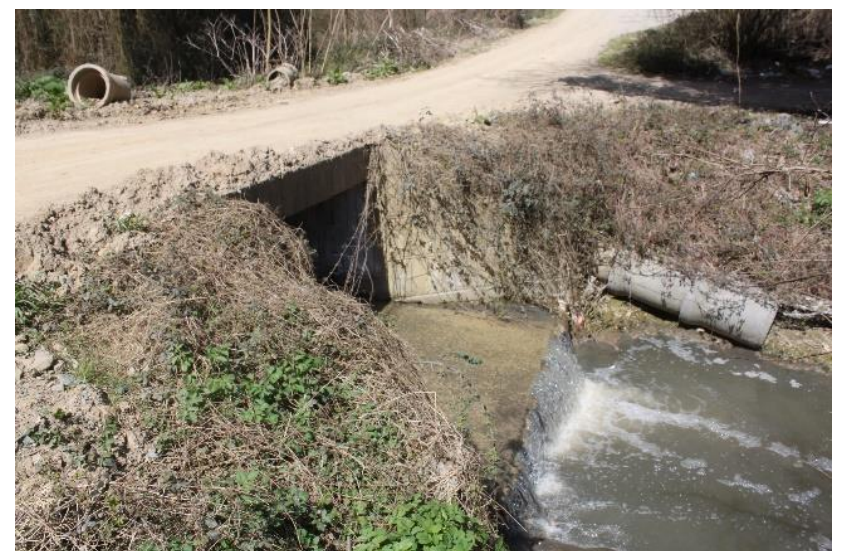

Figure 5. Completely open seventh culvert

route was incorrect. Only two of the culverts (number 2 and 7) were correctly positioned along the route. Since the culverts number 1, 3 and 6 among the other culverts were constructed perpendicular to the road axis, the waters coming from the dip drains or the stream could not enter the culvert completely and the entrance and exit parts of these culverts were filled mostly or completely because they left the sediment inside entrance and exit of the culvert. It is an important rule to position drainage structures such as cement water pipes and culverts at an angle of $30-45^{\circ}$ to the road route. The exit point of one culvert (number 4) was given to the dip drain of another connection road and the water coming from there flowed on the road after a certain distance. This caused the dip drains of the other road to be filled if the amount of water coming from the culvert was high. One of these culverts (number 5) was constructed on the route of the fire safety road, and since the entrance and exit grade of the culvert was quite below the road and at the same grade with each other, the sediment-filled both points. There was no point 
where the waters coming into the culvert would able to exit. Longitudinal slope was not applied inside these culverts constructed on the sample forest road. 2-5\% longitudinal slope should be given to the interior of the culverts constructed on the road routes (Özçelik, 1979; Bayoğlu, 1997; Erdaş, 1997; Anonymous, 2002).

The total cost of 7 culverts constructed on the forest road within the borders of Bentler Forest Management Directorate is calculated as approximately 27000 USD according to the exchange rate of August 2008. In addition to mistakes of the planning, dimensioning and positioning of culverts constructed along the road, the condition of the culverts was poor since they were not planned and periodic maintenance were not conducted. In this case, all the effort and cost made was written to the economic loss in the past 10 years. The drainage structures cost constituted about $25 \%$ of the total cost of forest road construction (Eskandri and Hosseini, 2013). All the culverts, except only the culvert number 7 in this area, completed their life in 10 years. However, usage lifetime of the culverts constructed on forest roads should be around 40 years (Rezvani, 2012). This drainage facility work was incomplete because the culverts were misplaced on the road route and the exit points were not connected to a stream channel. The positioning of culverts on the road should be at an angle of $30^{\circ}-45^{\circ}$ (Kramer, 2001; Ryan et.al., 2004; Fannin and Lorbach, 2007).

Areas which culverts are constructed along forest roads should not be planned on ridges or in hollow sections. In such cases, the culvert can't either pass the water to be drained to the stream or the water to be drained is collected in the hollow sections, but the water remains in the culvert because it can't find the path to drain. In this case, the sediment in the water subsides and clogs inside the culvert and its entrances. The erroneous and unplanned construction of the culverts in this way creates an economic loss and hinders the transportation of the forest road. This situation causes time, money and effort losses.

\section{Conclusions}

The drainage structures on a sample forest road were investigated by observing the changes of drainage structures over 10 years. In the light of results derived from this study, some suggestions are presented respectively as below:

- Planning of all kinds of drainage structures used on forest roads should be done appropriately. Based on the calculations made as a result of field studies, measurements and observations are very important in determining the type, size and location of the drainage structure.

- Drainage structures must be placed on the road route at an angle of $30^{\circ}-45^{\circ}$. It should not be placed perpendicular to the road.

- 2-5\% longitudinal slope should be applied to the interior of the pipes and culverts.

- Particular attention should be paid to material selection for constructing drainage structures.
- While deciding the places of culverts, the grades of field and road should be considered. When the grade of entrance is higher than the exit, it surely causes sediment and water accumulation inside the culvert.

- The landings should be prepared in size of $90-100 \mathrm{~cm}$ before the entrances of culverts. Thus, sediment coming with waters from dip drains will be massed on these landings and cleaned more easily during periodic maintenance.

- For each term, before and after forest field works, entrances and exits of drainage facilities should be cleaned by the help of an excavator.

- When placing the drainage structures in the designated area, the foundation excavation of the structure should be made up to the bedrock. If the foundation is not placed on solid ground, the culvert remains at high and the water that should pass through the culvert can flow through the foundation of the culvert.

\section{Ethics Committee Approval: N/A.}

\section{Peer-review: Externally peer-reviewed.}

Conflict of Interest: The authors have no conflicts of interest to declare.

Financial Disclosure: The authors declared that this study has received no financial support

Cite this paper as: Ozturk, T., 2020. Temporal Change of Drainage Structures in Forest Roads (Study of Bentler Forest Enterprise 2009-2019). European Journal of Forest Engineering 6(2): 52-59.

\section{References}

Akgul, M., Akburak, S., Yurtseven, H., Akay, A.O., Cigizoglu, H.K., Demir, M., Ozturk, T., Eksi, M., 2019. Potential Impacts of Weather and Traffic Conditions on Road Surface Performance in terms of Forest Operations Continuity. Applied Ecology and Environmental Research, 17(2): 2533-2550.

Anonymous, 2010. Forest Management Plan, Bentler Forest Enterprise Chief, Istanbul Forestry Regional Directorate, Istanbul.

Anonymous, 2009. How to Install a Forest Road Culvert. Forestry Services Division, Oklahoma Department of Agriculture, USA, pp.1-4.

Anonymous, 2010. Manual on Introduction to Forest Roads and Considerations for Reduced Impact Logging. Forestry Training Centre Incorporated Tropical Forest Foundation, Iwokrama, pp.21-22.

Anonymous, 2019. Forest Roads and Construction of Associated Water Diversion Devices. Forestry and Wildlife, Alabama Cooperative Extension System, ANR-0916, pp.1-4.

Bayoğlu, S., Hasdemir, M., 1991. Selection and sizing of small hydraulic road structures established on forest 
roads. Istanbul University Faculty of Forestry Journal, B41(3-4): 17-38.

Bayoğlu, S., 1997. Forest Transport Facilities and Vehicles. İstanbul University faculty of Forestry Publication, No. 434, İstanbul.

Çalışkan, E., Şentürk, N., Acar, H.H., 2006. Investigation of the hydraulic construction buildings in forest roads using GIS and GPS, Istanbul University Faculty of Forestry Journal, A56(2): 177190.

Erdaş, O., 1997. Forest Roads. Karadeniz Technical University, Faculty of Forestry Publication, No.26, Trabzon.

Eskandari, S., Hosseini, S.A., 2013. Assessment of drainage system standards of forest roads in Darabkola - Iran. Pol .J .Environ. Stud., 22(3): 675682.

Fannin, J.R., Lorbach, J., 2007. Guide to Forest Road Engineering in Mountainous Terrain. Forest Harvesting and Engineering Working Paper 2, Food and Agriculture Organization of the United Nations, Rome, pp.39-50.

Kalantari, Z., Folkeson, L., 2013. Road drainage in Sweden: Current practice and suggestions for adaptation to climate change. Journal of Infrastructure System, 19: 147-156.

Kramer, B.W., 2001. Forest Road Contracting, Construction, and Maintenance for Small Forest Woodland Owners. Oregon State University, Forest Research Laboratory, Research Contribution 35, pp.14-19.
OGM, 2008. Forest Roads Planning, Construction and Maintenance, Notification No. 292. General Directorate of Forestry, Construction and Supply Department Publication, Ankara.

Öztürk, T., 2010. Determination of necessary basis for positioning of drainage structures in forest roads (sample of Belgrad Forest), Proceedings of III. National Blacksea Forestry Congress, Vol 2, 20-22 May, Artvin, pp.494-504.

Özçelik, N., 1982. Road structures. İstanbul University, Faculty of Forestry Publication, No. 173, İstanbul.

Öztürk, T., İnan, M., 2010. Use of GIS for determination of positioning and sizes of drainage constructions at forest roads. III. National Remote Sensing and GIS Symposium, 11-13 October, İstanbul, pp.736-744.

Rezvani, M., 2012. Investigation of Drainage Structure of Forest Roads in North of Iran. Global Journal of Bio-Science and Biotechnology, 1(2): 220-222.

Ryan, T., Phillips, H., Ramsay, J., Dempsey, J, 2004. Forest Road Manual Guidelines for the Design, Construction and Management of Forest Roads. National Council for Forest Research and Development, Ireland, pp.111-112.

Schwab, J., 1994. Erosion Control: Planning, Forest Road Deactivation and Hillslope Revegetation. A Guide for Management of Landslide-Prone Terrain in the Pacific Northwest, Second Edition, Victoria, British Columbia.

URL-1, 2019. https://www.google.com.tr/intl/tr/earth/ 